\title{
PENGARUH BELANJA PEMERINTAH TERHADAP PERTUMBUHAN EKONOMI DAN PENGENTASAN KEMISKINAN DI KOTA BITUNG
}

\author{
Yeni Saarce Magdalena Lantu, Rosalina A.M. Koleangan, Tri Oldy Rotinsulu \\ Ekonomi Pembangunan - Fakultas Ekonomi dan Bisnis \\ Universitas Sam ratulangi
}

\begin{abstract}
ABSTRAK
Alokasi belanja dari pemerintah daerah merupakan salah satu indikator percepatan pembangunan yang terjadi di daerah, dimana alokasi belanja ini kemudian dibagi dalam dua kategori utama yakni belanja langsung dan belanja tidak langsung.

Melalui penelitian ini akan dibuktikan bagaimana alokasi belanja langsung dan belanja tidak langsung memberi pengaruh terhadap perkembangan perekonomian di kota Bitung yang dilihat dari pertumbuhan ekonomi serta bagaimana pengaruhnya terhadap tingkat kemiskinan yang terjadi. Penelitian ini sendiri akan menggunakan regresi berganda sebanyak dua kali, untuk melihat pengaruh masing-masing variabel independent terhadap masing-masing variabel dependent.
\end{abstract}

Kata kunci: Belanja langsung, Belanja Tidak Langsung, Pertumbuhan Ekonomi, Kemiskinan.

\begin{abstract}
The allocation of expenditure from local government is one of the indicators of the acceleration of development that occurs in the region, where the allocation of expenditure is then divided into two main categories namely direct expenditure and indirect spending.

Through this research will be proved how the allocation of direct expenditure and indirect spending gives effect to the economic development in the city of Bitung seen from the economic growth and how its influence on the level of poverty that occurred. This research alone will use multiple regression twice, to see the influence of each independent variable to each dependent variable .
\end{abstract}

Keywords: Direct Expenditure, Indirect Expenditure, Economic Growth, Poverty. 


\section{PENDAHULUAN}

\section{Latar Belakang}

Dimulainya era otonomi daerah menjadi ajang berpacu bagi daerah-daerah yang baru dimekarkan untuk maju dan berkembang. Dengan adanya otonomi daerah ini juga menjadi salah satu cara bagi pemerintah pusat untuk dapat memeratakan pembangunan secara nasional. Hal ini dikarenakan pemerintah daerah dianggap bisa lebih efektif dalam melakukan pembangunan di daerah, dikarenakan sudah mengenal dan mengetahui apa saja potensi dan kebutuhan yang dimiliki daerah yang bersangkutan. Babak baru penyelenggaraan pemerintahan ini dimulai sejak 1 januari 2001, dimana pemberian otonomi kepada seluruh wilayah baik propinsi, maupun kabupaten/kota yang merupakan perwujudan dari desentralisasi. Menurut UU No.23 tahun 2014 tentang pemerintahan daerah, untuk menunjang pelaksanaan pemerintahan daerah maka pemerintah pusat akan memberikan alokasi anggaran perimbangan kepada pemerintah daerah. Dimana dana tersebut terdiri dari Dana Alokasi Umum (DAU) yang pengalokasiannya diserahkan kewenangan kepada pemerintah daerah, Dana Alokasi Khusus (DAK) yang pengalokasiannya menyesuaikan dengan program pemerintah pusat yang ada di daerah maupun berdasarkan permintaan daerah yang berkenaan dengan kebutuhan nasional. Serta dana bagi hasil pajak dan bukan pajak. Selain mendapatkan alokasi anggaran dari pemerintah pusat, pemerintah daerah juga diharapkan untuk mampu meningkatkan kemampuan keuangannya sendiri melalui peningkatan kemandirian, agar perekonomian di daerah benar-benar dapat berkembang. Pendapatan Daerah sendiri selain dari alokasi transfer pemerintah pusat juga berasal dari Pendapatan Asli Daerah (PAD), Pinjaman Daerah (PD) serta lain-lain pendapatan yang sah. Setelah semua pendapatan daerah terkumpul baik yang berasal dari pemerintah pusat maupun yang berasal dari daerah maka, kebijakan penggunaan semua dana diserahkan kepada pemerintah daerah (Prakoso, 2004). Pengelolaan pemerintahan daerah tentu tak bisa lepas dari desentralisasi, dimana fungsi dari desentralisasi ini sendiri adalah melimpahkan kewenangan kepada pemerintah daerah, untuk meningkatkan kemampuan serta memacu potensi yang dimiliki oleh daerah, untuk dapat terus maju dan berkembang. Dengan diberlakukannya Undang-Undang nomor 23 tahun 2014 tentang pemerintahan daerah dengan nyawa otonomi daerah. Hal ini dimaksudkan agar pemerintahan dapat lebih mendekatkan diri kepada masyarakat agar pelayanan yang diberikan menjadi semakin baik. Dengan mendekatkan pemerintahan kepada masyarakat diharapkan pelayanan public dapat diwujudkan sesuai dengan kebutuahan masyarakat yang ada baik di pusat maupun daerah (Suparmoko, 2002). Tentunya pelaksanaan pemerintahan daerah tidak bisa berjalan sendiri tanpa mengetahui alokasi belanja yang tepat. Dimana saat ini alokasi anggaran belanja daerah dibagi menjadi alokasi Belanja langsung, yang terdiri dari belanja modal, belanja barang jasa, dan belanja pegawai, alokasi belanja langsung ini juga sering dikenal dengan belanja pembangunan, dikarenakan alokasi anggaran yang ada di dalamnya benar-benar di alokasikan untuk pembangunan baik infrastruktur maupun sumber daya manusia. Selain itu juga terdapat alokasi belanja tidak langsung, dimana pengalokasian anggaran ini lebih banyak ditujukan untuk alokasi belanja social, seperti belanja bantuan social, belanja pegawai, belanja transfer kepada pemerintah dibawah, dan lain-lain alokasi belanja yang tidak berkaitan langsung dengan pembangunan. Kota Bitung merupakan salah satu daerah di Sulawesi Utara yang perkembangannya cukup menjanjikan, dimana salah satunya adalah perkembangan kota yang sedikit demi sedikit mulai beralih dari daerah agraris menjadi daerah industrialis, hal ini tentu saja memberi pengaruh yang cukup signifikan terhadap alokasi anggaran kota Bitung. Seperti yang dapat dilihat pada table dibawah. 
Tabel 1 Alokasi Belanja Langsung dan Belanja tidak langsung kota Bitung

\begin{tabular}{|l|l|l|}
\hline Tahun & Belanja Langsung & Belanja Tidak Langsung \\
\hline 2006 & $\begin{array}{l}125.420 .668 .706 \\
\text { (belanja pelayanan public) }\end{array}$ & $\begin{array}{l}139.350 .133 .181 \\
\text { (belanja aparatur) }\end{array}$ \\
\hline 2007 & $\begin{array}{l}79.396 .280 .670 \\
\text { (belanja modal) }\end{array}$ & $\begin{array}{l}243.602 .370 .291 \\
\text { (Belanja Operasi) }\end{array}$ \\
\hline 2008 & 178.456 .048 .472 & 188.504 .371 .606 \\
\hline 2009 & 194.423 .691 .262$, & 221.893 .084 .174 \\
\hline 2010 & $255,056,120,128$ & $204,667,916,666$ \\
\hline 2011 & 277.500 .010 .298 & 138.326 .308 .076 \\
\hline 2012 & 223.985 .713 .250 & 300.803 .201 .309 \\
\hline 2013 & $294,927,859,461$ & $287,439,582,071$ \\
\hline 2014 & 352.453 .665 .929 & 346.654 .614 .841 \\
\hline 2015 & $296,553,356,700$ & $371,001,480,300$ \\
\hline
\end{tabular}

Sumber : BPS Kota Bitung (data diolah)

Seperti dapat dilihat pada table 1 di atas, menunjukan bahwa alokasi belanja langsung dari tahun awal data yakni tahun 2006 sebesar 125 Miliar rupiah, terus mengalami pertumbuhan yang positif secara keseluruhan, meskipun alokasi anggaran belanja langsung kota Bitung masih berfluktuatif setiap tahunnya. Hal yang sama juga terjadi pada alokasi anggaran belanja tidak langsung dimana sejak tahun awal data hingga tahun akhir data terus mengalami fluktuatif setiap tahunnya. Namun secara keseluruhan mengalami pertumbuhan yang cukup baik dimana alokasi belanja langsung dari $125 \mathrm{M}$ rupiah pada tahun 2006 menjadi $296 \mathrm{M}$ rupiah pada tahun 2015, begitupun dengan alokasi belanja tidak langsung dari $139 \mathrm{M}$ rupiah pada tahun 2006 menjadi $371 \mathrm{M}$ rupiah pada 2015. Berdasarkan alokasi belanja baik langsung maupun tidak langsung pemerintah kota Bitung dapat merencanakan pembangunan ekonomi yang diprioritaskan, dimana alokasi belanja ini ditujukan untuk dapat meningkatkan kemandirian daerah serta memacu potensi-potensi yang dimiliki oleh daerah yang tujuannya tentu saja mensejahterakan masyarakat yang ada. Selain meningkatkan pertumbuhan ekonomi di daerah yang menandakan total pendapatan yang ada di daerah terus bertumbuh, namun juga salah satu tujuan utama pemerintah adalah mereduksi kemiskinan yang ada sehingga pertumbuhan pendapatan yang ada bukan hanya menjadi milik sebagian masyarakat yang memang sudah mempunyai pendapatan sebelumnya, dan hanya meningkatkan pendapatan yang diterima namun juga mereduksi kemiskinan di mana pertumbuhan pendapatan juga menjadi milik masyarakat yang sebelumnya belum mampu bahkan tidak mempunyai pendapatan sebelumnya. Berdasarkan uraian tersebut di atas maka sangat menarik untuk melihat dan mengkaji kembali sebagaimana pengalokasian belanja yang dilakukan oleh pemerintah kota Bitung melalui alokasi anggaran belanja langsung dan belanja tidak langsung, terhadap pertumbuhan ekonomi kota Bitung serta perkembangan tingkat kemiskinan yang ada di Kota Bitung.

\section{Rumusan Masalah}

Berdasarkan latar belakang yang telah diuraikan di atas maka rumusan masalah yang dapat diambil adalah :

1. Bagaimana pengaruh Belanja Langsung terhadap Pertumbuhan Ekonomi Kota Bitung ?

2. Bagaimana pengaruh Belanja tidak Langsung terhadap Pertumbuhan Ekonomi Kota Bitung $?$

3. Bagaimana pengaruh Belanja Langsung terhadap tingkat Kemiskinan Kota Bitung ?

4. Bagaimana pengaruh Belanja tidak Langsung terhadap tingkat Kemiskinan Kota Bitung ? 


\section{Tujuan Penelitian}

Berdasarkan rumusan masalah di atas maka tujuan penelitian ini adalah untuk memberikan bukti kajian pada :

1. Untuk mengetahui bagaimana pengaruh belanja langsung dan belanja tidak langsung terhadap pertumbuhan ekonomi kota Bitung

2. Untuk mengetahui bagaimana pengaruh belanja langsung dan belanja tidak langsung terhadap Tingkat Kemiskinan kota Bitung

\section{Manfaat Penelitian}

Beberapa manfaat yang dapat diambel dalam penelitian ini adalah :

1. Kontibusi data kajian terhadap pengaruh belanja langsung dan belanja tidak langsung terhadap pertumbuhan ekonomi kota Bitung, serta pengaruh belanja langsung dan belanja tidak langsung terhadap tingkat kemiskinan yang ada di kota bitung

2. Sebagai bahan masukan bagi pembuat kebijakan, terlebih dalam pengelolaan keuangan/fiscal, baik pemerintah pusat maupun daerah.

3. Sebagai bahan referensi bagi penelitian selanjutnya

\section{Jenis dan Sumber Data}

\section{METODE PENELITIAN}

Data yang digunakan dalam penelitian ini adalah data sekunder atau mengambil data yang sudah tersedia di instansi tertentu yang sesuai dengan jenis penelitian dan dalam penelitian ini mengambil data dari Badan Perencanaan dan Pembangunan Bitung (Bappeda) dan dari badan pusat Statistik (BPS) Provinsi Sulawesi Utara.

\section{Metode Pengumpulan Data}

Metode pengambilan data sekunder, data dikumpulkan dengan metode dokumentasi. Ini dilakukan dengan mengumpulkan, mencatat dan menghitung data-data yang berhubungan dengan penelitian. Penelitian ini mengambil data dari APBD Kota Bitung tahun 2006 sampai 2015 dan statistic PDRB di tahun yang sama.

\section{Metode Analisis}

Penelitian ini dengan menggunakan pendekatan kuantitatif. Secara umum, pendekatan kuantitatif lebih fokus pada tujuan untuk generalisasi, dengan melakukan pengujian statistik dan steril dari pengaruh subjektif peneliti (Sekaran, 1992). Alat analisis yang digunakan dalam penelitian ini adalah analisis regresi linier berganda. Analisis regresi berganda adalah analisis mengenai beberapa variabel independen dengan satu variabel dependen. Secara umum, analisis regresi adalah analisis mengenai variabel independen dengan variabel dependen yang bertujuan untuk mengestimasi nilai rata-rata variabel dependen berdasarkan nilai variabel independen yang diketahui (Gujarati, 2003). Teknik yang digunakan untuk mencari nilai persamaan regresi yaitu dengan analisis Least Squares (kuadrat terkecil) dengan meminimalkan jumlah dari kuadrat kesalahan.

Dalam analisis regresi selain mengukur seberapa besar hubungan antara variabel independen dengan variabel dependen, juga menunjukkan bagaimana hubungan antara variabel independen dengan dependen, sehingga dapat membedakan variabel independen dengan variabel dependen tersebut (Ghozali, 2006). Dimana dalam penelitian ini, dua komponen dari belanja langsung dan belanja tidak langsung akan dianalisis pengaruhnya terhadap pertumbuhan ekonomi dan tingkat kemiskinan sebagai variabel dependen. Beberapa langkah yang dilakukan dalam analisis regresi linier masing- masing akan dijelaskan di bawah ini: 


\section{Analisis Regresi Linier Berganda}

Dalam penelitian ini data dianalisis menggunakan analisis regresi linier berganda (multiple linier regression). Data diolah dengan program SPSS 20 for Windows. Teknik ini digunakan untuk menganalisis pengaruh variabel independen terhadap variabel dependen. Formula dalam penelitian ini adalah sebagai berikut:

Dimana :

$$
\begin{aligned}
& Y=\alpha+\beta_{1} X_{1}+\beta_{2} X_{2}++\varepsilon \\
& Y 2=\alpha+\beta_{1} X_{1}+\beta_{2} X_{2}++\varepsilon
\end{aligned}
$$

\begin{tabular}{|c|c|c|}
\hline $\mathrm{Y}$ & $=$ & Pertumbuhan Ekonomi \\
\hline Y2 & $=$ & Kemiskinan \\
\hline$\alpha$ & $=$ & Konstanta \\
\hline$\beta_{1}$ & $=$ & Koefisien regresi untuk $X_{1}$ \\
\hline$\beta_{2}$ & $=$ & Koefisien regresi untuk $X_{2}$ \\
\hline $\mathrm{X}_{1}$ & $=$ & Belanja Langsung \\
\hline $\mathrm{X}_{2}$ & $=$ & Belanja Tidak Langsung \\
\hline $\boldsymbol{\varepsilon}$ & $=$ & Variabel sisa yang tidak diteliti \\
\hline
\end{tabular}

\section{Statistik Deskriptif}

Penyajian statistik deskriptif bertujuan agar dapat dilihat profil dari data penelitian tersebut dengan hubungan yang ada antar variabel yang digunakan dalam penelitian tersebut. Dalam penelitian ini variabel yang digunakan adalah Pendapatan pajak, retribusi dan PAD lain yang sah serta belanja langsung.

\section{Uji Asumsi Klasik}

Pengujian regresi linier berganda dapat dilakukan setelah model dari penelitian ini memenuhi syarat-syarat yaitu lolos dari asumsi klasik. Syarat-syarat yang harus dipenuhi adalah data tersebut harus terdistribusikan secara normal, tidak mengandung multikoloniaritas, dan heterokedastisitas. Untuk itu sebelum melakukan pengujian regresi linier berganda perlu dilakukan lebih dahulu pengujian asumsi klasik, yang terdiri dari:

\section{Uji Normalitas}

Pengujian normalitas memiliki tujuan untuk menguji apakah dalam model regresi, variabel penganggu atau residual memiliki distribusi normal. Seperti diketahui bahwa uji t mengasumsikan bahwa nilai residual mengikuti distribusi normal. Kalau asumsi ini dilanggar maka uji statistik menjadi tidak valid untuk jumlah sampel kecil. Untuk menguji normalitas data, penelitian ini menggunakan analisis grafik. Pengujian normalitas melalui analisis grafik adalah dengan cara menganalisis grafik normal probability plot yang membandingkan distribusi kumulatif dari distribusi normal. Distribusi normal akan membentuk satu garis lurus diagonal, dan ploting data residual akan dibandingkan dengan garis diagonal. Data dapat dikatakan normal jika data atau titik-titk terbesar di sekitar garis diagonal dan penyebarannya mengikuti garis diagonal.

Pada prinsipnya normalitas dapat dideteksi dengan melihat penyebaran data (titik) pada sumbu diagonal dari grafik atau dengan melihat histrogram dari residualnya. Dasar pengambilan keputusan: Jika data menyebar disekitar garis diagonal dan mengikuti arah garis diagonal atau grafik histrogramnya menunjukan pola distribusi normal, maka model regresi memenuhi asumsi normalitas. Jika data menyebar lebih jauh dari diagonal dan/atau tidak mengikuti arah garis diagonal atau grafik histrogram tidak menunjukkan pola distribusi normal, maka model regresi tidak memenuhi asumsi normalitas (Ghozali, 2006). Uji statistik yang dapat digunakan untuk menguji normalitas residual adalah uji statistik non-parametrik Kolmogrov-Smirnov (K-S). Jika 
hasil Kolmogrov-Smirnov menunjukkan nilai signifikan diatas 0,05 maka data residual terdistribusi dengan normal. Sedangkan jika hasil Kolmogrov-Smirnov menunjukkan nilai signifikan dibawah 0,05 maka data residual terdistribusi tidak normal (Ghozali, 2006).

\section{Uji Multikolinearitas}

Uji Multikolonieritas bertujuan untuk menguji apakah model regresi ditemukan adanya korelasi antar variabel bebas (Ghozali, 2006). Uji multikolonieritas ini digunakan karena pada analisis regresi terdapat asumsi yang mengisyaratkan bahwa variabel independen harus terbebas dari gejala multikolonieritas atau tidak terjadi korelasi antar variabel independen. Cara untuk mengetahui apakah terjadi multikolonieritas atau tidak yaitu dengan melihat nilai Tolerance dan Variance Inflation Factor (VIF). Kedua ukuran ini menunjukkan setiap variabel independen manakah yang dijelaskan oleh variabel independen lainnya. Dalam pengertian sederhana setiap variabel independen menjadi variabel dependen (terikat) dan diregresi terhadap variabel independen lainnya. Tolerance mengukur variabilitas variabel independen yang terpilih yang tidak dijelaskan oleh variabel independen lainnya. Jadi nilai Tolerance yang rendah sama dengan nilai VIF tinggi (karena VIF $=1 /$ Tolerance). Nilai cutoff yang umum dipakai untuk menunjukkan adanya multikolinearitas adalah nilai Tolerance $<0,10$ atau sama dengan nilai VIF $>10$ (Ghozali, 2006).

\section{Uji Autokorelasi}

Uji autokorelasi bertujuan menguji apakah dalam model regresi berganda linier ada korelasi antara kesalahan penganggu pada periode $t$ dengan kesalahan penganggu pada periode t1(sebelumnya). Autokorelasi muncul karena observasi yang berurutan sepanjang waktu berkaitan satu sama lain. Jika ada masalah autokorelasi, maka model regresi yang seharusnya signifikan, menjadi tidak layak untuk dipakai (Singgih Santoso, 2000). Autokorelasi dalam penelitian ini menggunakan uji statistik Durbin Watson. Singgih (2000), bila angka D-W diantara -2 samapai +2, berarti tidak terjadi autokorelasi. Menurut Ghozali (2006), untuk mendeteksi ada atau tidaknya autokorelasi bisa menggunakan Uji Durbin-Watson (DW test)

Tabel 2 Pengambilan keputusan ada tidaknya autokorelasi

\begin{tabular}{|l|l|l|}
\hline \multicolumn{1}{|c|}{ Hipotesis nol } & \multicolumn{1}{c|}{ Keputusan } & Jika \\
\hline Tdk ada autokorelasi positif & Tolak & $0<\mathrm{d}<\mathrm{dl}$ \\
\hline Tdk ada autokorelasi positif & No decision & $\mathrm{dl} \leq \mathrm{d} \leq \mathrm{du}$ \\
\hline Tdk ada autokorelasi negatif & Tolak & $4-\mathrm{dl}<\mathrm{d}<4$ \\
\hline Tdk ada autokorelasi negatif & No decision & $4-\mathrm{du} \leq \mathrm{d} \leq 4-\mathrm{dl}$ \\
\hline $\begin{array}{l}\text { Tdk ada autokorelasi, positif atau } \\
\text { negatif }\end{array}$ & Tdk ditolak & $\mathrm{du}<\mathrm{d}<4-\mathrm{du}$ \\
\hline
\end{tabular}

Sumber: Imam Ghozali, 2006

\section{Uji Heteroskedastisitas}

Pengujian ini memiliki tujuan untuk menguji apakah dalam model regresi terjadi ketidaksamaan variance dari residual satu pengamatan ke pengamatan yang lain atau untuk melihat penyebaran data. Jika variance dari residual satu pengamatan ke pengamatan yang lain tetap, maka disebut Homokedastisitas dan jika berbeda disebut Heteroskedastisitas. Model regresi yang baik adalah tidak terdapat heteroskedastisitas. Uji ini dapat dilakukan dengan melihat gambar plot antara nilai prediksi variabel independen (ZPRED) dengan residualnya (SRESID). Apabila dalam grafik tersebut tidak terdapat pola tertentu yang teratur dan data tersebar secara acak di 
atas dan di bawah angka 0 pada sumbu Y, maka diidentifikasikan tidak terdapat heteroskedastisitas (Ghozali,2006).

\section{Model Regresi}

Alat analisis yang digunakan adalah analisis regresi berganda linier yang digunakan untuk melihat pengaruh pendapatan yaitu PAD dan DAU terhadap pengeluaran pemerintah yang berupa alokasi belanja daerah (belanja langsung dan belanja tidak langsung). Data diolah dengan bantuan software SPSS seri 21.00. Pengujian hipotesis dilakukan dengan menggunakan model analisis regresi variabel independen terhadap variabel dependen (sekaran, 1992).

\section{Uji Hipotesis}

Ketepatan fungsi regresi sampel dalam menaksir nilai aktual dapat diukur dari Goodness of Fitnya. Secara statistik, setidaknya ini dapat diukur dari nilai koefisien determinasi, nilai statistik F dan nilai statistik t. Perhitungan statistik disebut signifikan secara statistik apabila nilai uji statistiknya berada dalam daerah kritis (daerah dimana Ho ditolak). Sebaliknya disebut tidak signifikan bila nilai uji statistiknya berada dalam daerah dimana Ho diterima (Ghozali, 2006).

\section{Koefisien Determinasi}

Koefisien determinasi $\left(\mathrm{R}^{2}\right)$ pada intinya mengukur seberapa jauh kemampuan model dalam menerangkan variasi variabel independen. Koefisien determinasi ini digunakan karena dapat menjelaskan kebaikan dari model regresi dalam memprediksi variabel dependen. Semakin tinggi nilai koefisien determinasi maka akan semakin baik pula kemampuan variabel independen dalam menjelaskan variabel dependen (Ghozali, 2006). Nilai koefisien determinasi adalah antara nol dan satu. Nilai $\mathrm{R}^{2}$ yang kecil berarti kemampuan variabel-variabel independen dalam menjelaskan variasi variabel dependen amat terbatas. Nilai yang mendekati satu berarti variabel- variabel independen memberikan hampir semua informasi yang dibutuhkan untuk memprediksi variasi variabel dependen.

\section{Uji Signifikansi Simultan (Uji Statistik F)}

Uji Statistik F pada dasarnya menunjukkan apakah semua variabel independen atau bebas yang dimasukkan dalam model mempunyai pengaruh secara bersama-sama terhadap variabel dependen (Ghozali, 2006). Cara untuk mengetahuinya yaitu dengan membandingkan nilai $\mathrm{F}$ hitung dengan nilai $\mathrm{F}$ tabel. Apabila nilai $\mathrm{F}$ hitung lebih besar daripada nilai $\mathrm{F}$ tabel, maka hipotesis alternatif diterima artinya semua variabel independen secara bersama-sama dan signifikan mempengaruhi variabel dependen.

\section{Uji Signifikansi Parameter Individual (Uji Statistik t)}

Uji statistik t pada dasarnya menunjukkan seberapa jauh pengaruh satu variabel independen secara individual dalam menerangkan variasi variabel dependen (Ghozali, 2006). Uji statistik t ini digunakan karena untuk memperoleh keyakinan tentang kebaikan dari model regresi dalam memprediksi. Cara untuk mengetahuinya yaitu dengan membandingkan nilai t hitung dengan nilai $t$ tabel. Apabila nilai t hitung lebih besar dibandingkan dengan nilai t tabel maka berarti $t$ hitung tersebut signifikan artinya hipotesis alternatif diterima yaitu variabel independen secara individual mempengaruhi variabel dependen. Selain itu, bisa juga dilakukan dengan melihat $p$-value dari masing-masing variabel. Hipotesis diterima apabila $p$-value $<5 \%$ (Ghozali, 2006). 


\section{Kerangka Pemikiran}

Gambar 1 Pengaruh belanja langsung dan belanja tidak langsung terhadap pertumbuhan ekonomi dan kemiskinan

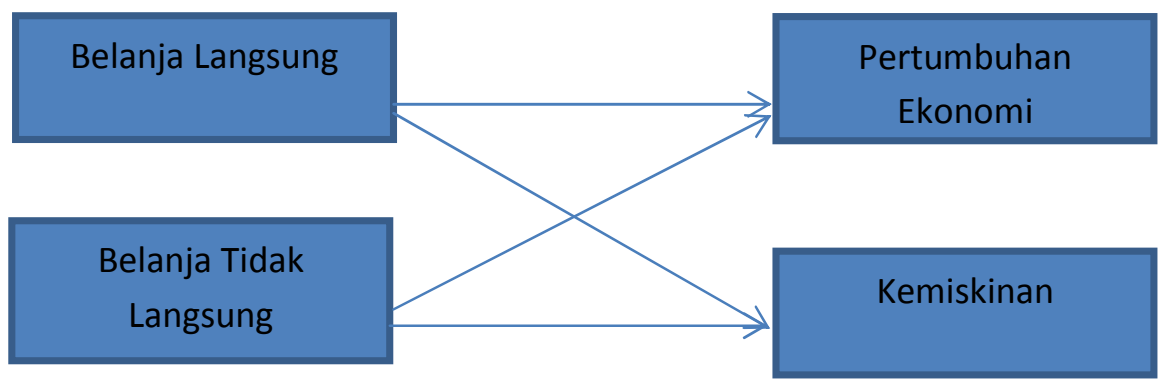

\section{HASIL PENELITIAN DAN PEMBAHASAN}

\section{Perhitungan Struktur I}

Pengujian Asumsi klasik

Multikolerasi

Tabel 3 VIF Coefficients ${ }^{\mathrm{a}}$

\begin{tabular}{|ll|l|}
\hline Model & Collinearity Statistics \\
\cline { 3 - 3 } & & VIF \\
\hline 1 & (Constant) & \\
& BL & 1.669 \\
& BTL & 1.669 \\
\hline
\end{tabular}

a. Dependent Variable: PE

Sumber Data : pengolahan data 2017

Dilihat dari tabel 3 Coefficients nilai VIF pada Output menunjukkan keberadaan multikolinearitas

Bila VIF $<10,00$ maka tidak terjadi gejala Multikolerasi

Bila VIF > 10,00 maka terjadi gejala Multikolerasi

Dengan Hasil :

$$
\begin{array}{rll}
\text { Nilai VIF } & \text { X1 BL } & =1.669 \\
\text { X2 BTL } & =1.669
\end{array}
$$

Dari hasil perhitungan di atas dapat dilihat bahwa nilai VIF kedua variable independent berada pada angka dibawah 10 hal ini menunjukan bahwa tidak terjadi gejala multikolinearitas sehingga data penelitian layak dan dapat digunakan. 


\section{Diagram Uji Heterokoledasitas}

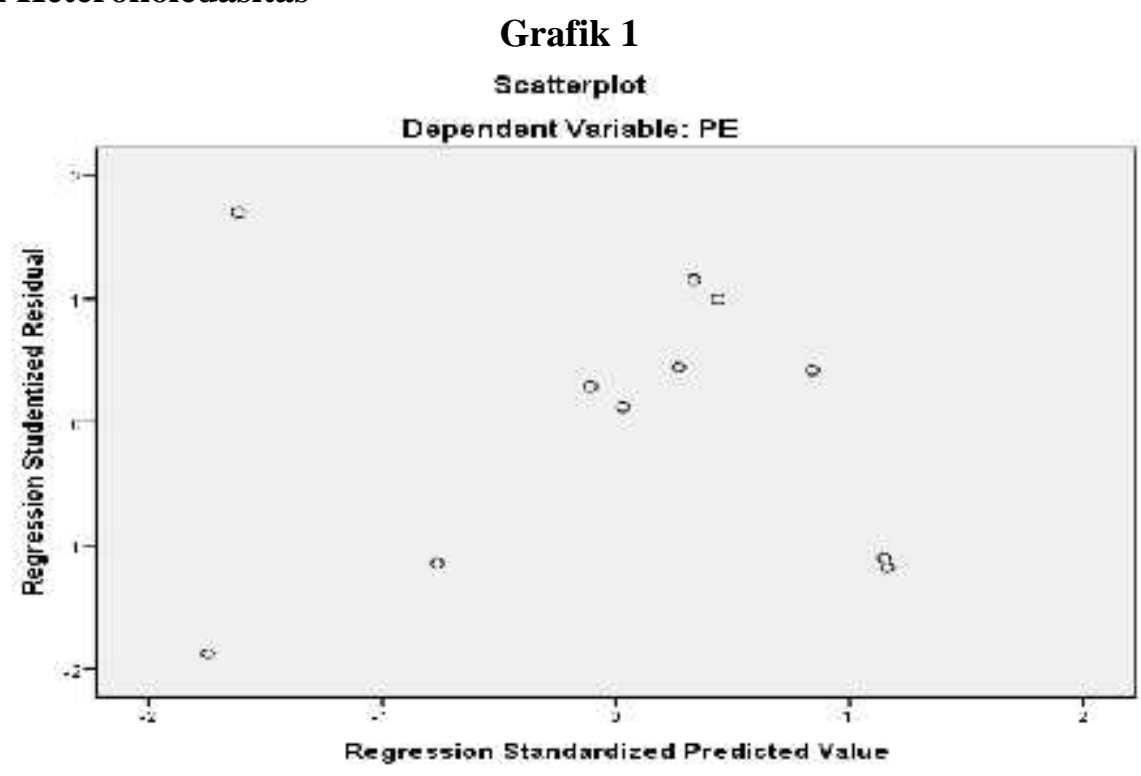

Dari diagram diatas tersebut terlihat bahwa penyebaran residual tidak teratur. Hal tersebut terlihat pada plot yang terpancar dan tidak membentuk pola tertentu. Dengan hasil demikian, kesimpulan yang biasa diambil adalah bahwa tidak terjadi gejala homokedastisitas atau persamaan regresi memenuhi asumsi heterokedatisitas.

\section{Uji Autokorelasi}

Tabel 4 Model Summary ${ }^{\mathrm{b}}$

\begin{tabular}{|l|l|l|l|}
\hline Model & Change Statistics & Durbin-Watson \\
& df2 & Sig. F Change & \\
\hline 1 & $8^{\mathrm{a}}$ & .015 & 1.056 \\
\hline
\end{tabular}

a. Predictors: (Constant), BTL, BL

b. Dependent Variable: PE

Sumber Data : pengolahan data 2017

Pada analisis regresi telihat bahwa nilai DW 1.821 dan nilai DL 0.455 , dan DU 2,287 . DL < DW < DU yakni 0.455 DL, 1,056 DW, 2.287 DU. berada pada antara DL dan DU dan berada pada titik tengah. Maka dapat disimpulkan bahwa terdapat gejala autokorelasi yang lemah. Hasil Perhitungan (output) untuk substruktur satu dengan menggunakan SPSS 21,0 adalah sebagai berikut : 
Tabel 5 Correlations

\begin{tabular}{|ll|l|l|l|}
\hline & & PE & BL & BTL \\
\hline Pearson Correlation & BE & 1.000 & .804 & .786 \\
& BTL & .804 & 1.000 & .952 \\
Sig. (1-tailed) & PE &. & .952 & 1.000 \\
& BL & .001 & .001 & .002 \\
& BTL & .002 & .000 & .000 \\
& PE & 11 & 11 & 11 \\
N & BL & 11 & 11 & 11 \\
BTL & 11 & 11 & 11 \\
\hline
\end{tabular}

Sumber Data : pengolahan data 2017

Dari tabel 5 Correlations diatas menunjukan bahwa Koefisien Korelasi Pearson Belanja Langsung dengan alokasi Pertumbuhan ekonomi adalah 0,804 dengan nilai sig 0,001, koefisien korelasi antara Belanja tidak langsung dan Pertumbuhan Ekonomi. Dari hasil tabel Correlations diatas menunjukan 0,786 dengan nilai signifikan 0,002. Dengan demikian dilihat dalam kondisi tersebut dimana nilai signifikan < 0,05. Maka kesimpulan yang diambil adalah H0 di tolak, dan H1 di terima. Yang berarti Koefisien Korelasi adalah signifikan secara statistik.

\section{Penhitungan Koefisien Determinasi}

\begin{tabular}{|l|l|l|l|l|l|l|l|}
\hline Model & $\mathrm{R}$ & R Square & $\begin{array}{l}\text { Adjusted R } \\
\text { Square }\end{array}$ & $\begin{array}{l}\text { Std. Error of the } \\
\text { Estimate }\end{array}$ & $\begin{array}{l}\text { Change Statistics } \\
\text { R Square } \\
\text { Change }\end{array}$ & F Change & df1 \\
\hline 1 & $.807^{\mathrm{a}}$ & .651 & .564 & 148.82633 & .651 & 7.465 & 2 \\
\hline
\end{tabular}

a Predictors: (Constant), BL, BTL . b Dependent Variable: Pertumbuhan Ekonomi

Sumber Data : pengolahan data 2017

Dalam melihat pengaruh Variabel Independen Exogenus Belanja Langsung dan Belanja Tidak Langsung secara gabungan terhadap variabel Dependen Endogenus Pertumbuhan Ekonomi dapat dilihat dari Tabel 4.5 Model Summary diatas, pada nilai $R$ square. Besarnya $R$ square $\left(\mathrm{R}^{2}\right)$ pada tabel dibawah ini adalah 0,651. Angka tersebut mempumpunyai makna Besarnya pengaruh Variabel indeependen exogenous Belanja Langsung dan Belanja tidak langsung terhadap variabel dependen endogenus Pertumbuhan Ekonomi secara gabungan. Dalam menghitung Koefisien Determinasi (KD) dapat diketahui dengan rumus

$$
\begin{aligned}
& \mathrm{KD}=\mathrm{R} 2 \times 100 \% \\
& \mathrm{KD}=0,651 \times 100 \% \\
& \mathrm{KD}=65,1 \%
\end{aligned}
$$

Besarnya pengaruh Variabel Independen Exogenous Belanja Langsung dan Belanja Tidak langsung terhadap Variabel Dependen Endogenus Pertumbuhan Ekonomi secara gabungan adalah 65,1 \%. Dan pengaruh di luar model dapat di hitung dengan rumus :

$$
\begin{aligned}
& \mathrm{e}=1-\mathrm{R}^{2} \\
& \mathrm{e}=1-0,349 \\
& \mathrm{e}=0,349 \times 100 \%
\end{aligned}
$$




$$
\mathrm{e}=34,9 \%
$$

Yang berarti 34,9\% besarnya faktor lain yang mempengaruhi diluar model yang di teliti. Artinya besarnya pengaruh variabel independen eksogenus Belanja Langsung dan Belanja Tidak langsung terhadap variabel dependen endogenus Pertumbuhan Ekonomi adalah sebesar 65,1\%, sedangkan pengaruh sebesar 34,9\% disebabkan oleh variabel di luar model yang di teliti.

\section{Pengaruh variabel independen exogenous Belanja Langsung dan Belanja tidak Langsung secara parsial terhadap variabel dependen endogenus Pertumbuhan Ekonomi.}

Besarnya pengaruh variabel independen exogenous Belanja langsung dan Belanja tidak langsung terhadap variabel dependen endogenus Pertumbuhan Ekonomi secara Parsial dapat dilihat dari nilai Beta atau Standardized Coefficients .dan untuk pengujian digunakan nilai t. Dapat dilihat pada Tabel 7 dibawah ini.

Tabel 7 t Coefficients(a)

\begin{tabular}{|c|c|c|c|c|c|c|}
\hline \multirow{2}{*}{\multicolumn{2}{|c|}{ Model }} & \multicolumn{2}{|c|}{ Unstandardized Coefficients } & \multirow{2}{*}{$\begin{array}{l}\text { Standardized } \\
\text { Coefficients } \\
\text { Beta }\end{array}$} & \multirow[t]{2}{*}{$\mathrm{t}$} & \multirow[t]{2}{*}{ Sig. } \\
\hline & & B & Std. Error & & & \\
\hline \multirow{3}{*}{1} & (Constant) & -8193.310 & 2574.586 & & -3.182 & .013 \\
\hline & BL & 542.904 & 626.053 & .592 & .867 & |.411 \\
\hline & BTL & 235.260 & 718.840 & .223 & .327 & .752 \\
\hline
\end{tabular}

a. Dependent Variable: Pertumbuhan Ekonomi

Sumber Data : pengolahan data 2017

\section{Pengaruh Variabel Independen Exogenous Belanja Langsung terhadap Variabel Dependen Endogenus Pertumbuhan Ekonomi.}

Untuk melihat apakah ada Pengaruh Linier Variabel Independen Exogenus Belanja Langsung terhadap Variabel Dependen Endogenus pertumbuhan ekonomi. Dapat dilihat pada tabel 7 Coefficients(a) Dengan Analisis Hipotesis :

H0 : Tidak ada pengaruh linier antara Variabel Independen Exogenus Belanja langsung terhadap Variabel Dependen Endogenus Pertumbuhan Ekonomi.

H1 : Ada Pengaruh linier antara Variabel Independen Exogenus Belanja Langsung terhadap Variabel Dependen Endogenus Pertumbuhan Ekonomi

Menentukan besarnya taraf Signifikan sebesar 0,05 dan Degree of Freedom DF $=n-(K+1)$ atau $\mathrm{DF}=10-(2+1)=7$. Dari ketentuan tersebut diperoleh $\mathrm{t}$ tabel sebesar 1,894 (untuk uji dua arah) Dalam perhitungan SPSS yang tertera pada tabel Coefficients di atas dimana $t$ hitung adalah untuk menunjukan bahwa adanya Pengaruh linier antara Variabel Independen Exogenus Belanja Langsung terhadap Variabel Dependen Endogenus Pertumbuhan Ekonomi ialah 0,867..

Pengujian Hipotesis t kriterianya sebagai berikut :

Jika thitung > t tabel, maka $\mathrm{H} 0$ ditolak, dan $\mathrm{H} 1$ diterima

Jika t hitung < $\mathrm{t}$ tabel, maka $\mathrm{H} 0$ diterima, dan $\mathrm{H} 1$ ditolak

Dimana dalam melihat pengaruh signifikan atau tidak Kriterianya adalah sebagai berikut :

Jika Signifikan $<0,05$ maka berpengaruh signifikan

Jika Signifikan >0,05 maka tidak ada pengaruh signifikan

Hasil dari perhitungan dengan SPSS menunjukan angka t hitung sebesar $0,867<\mathrm{t}$ tabel sebesar 1,894. Dengan demikian keputusanya ialah H0 diterima, dan H1 ditolak. Artinya tidak ada hubungan linier antara Variabel Independen Exogenus Belanja langsung terhadap Variabel Dependen Endogenus Pertumbuhan Ekonomi. Maka Variabel Independen Exogenus Belanja langsung tidak berpengaruh terhadap Variabel Dependen Endogenus Pertumbuhan Ekonomi. 
Besarnya Koefisien Beta pada tabel 4.6 di atas (dalam kolom Standardized Coefficient Beta) sebesar 0,592 atau jika dibuat persen menjadi sebesar 59,2\% menunjukan bahwa pengaruh sebesar ini tidak mampu menjelaskan perubahan yang terjadi pada Belanja Langsung, terlebih karena karena nilai signifikansi / probabilitas hasil yang tertera pada kolom Sig 0,411 >0,05. Hal ini disebabkan karena alokasi belanja tidak langsung memang masih amat kecil tertata dalam alokasi belanja pemeintah daerah, sehingga menyebabkan pengaruh terhadap pertumbuhan ekonomi yang terjadi di kota Bitung masih amat kecil. Dampak yang ditimbulkan oleh alokasi belanja tidak langsung masih amat sangat kecil terhadap pengaruhnya terhadap pertumbuhan perekonomian yang terjadi.

\section{Pengaruh antara variabel Independen Exogenus Belanja Langsung terhadap Variabel Dependen Endogenus Pertumbuhan Ekonomi.}

Untuk melihat apakah ada Pengaruh Linier Variabel Independen Exogenus Belanja Tidak langsung terhadap Variabel Dependen Endogenus pertumbuhan ekonomi. Dapat dilihat pada tabel 7 Coefficients(a) Dengan Analisis Hipotesis :

H0 : Tidak ada pengaruh linier antara Variabel Independen Exogenus Belanja tidak langsung terhadap Variabel Dependen Endogenus Pertumbuhan Ekonomi.

H1 : Ada Pengaruh linier antara Variabel Independen Exogenus belanja tidak langsung terhadap Variabel Dependen Endogenus pertumbuhan ekonomi.

Menentukan besarnya taraf Signifikan sebesar 0,05 dan Degree of Freedom DF $=n-(K+1)$ atau $\mathrm{DF}=10-(2+1)=7$. Dari ketentuan tersebut diperoleh t tabel sebesar 1,894 (untuk uji dua arah) Dalam perhitungan SPSS yang tertera pada tabel Coefficients di atas dimana $t$ hitung adalah untuk menunjukan bahwa adanya Pengaruh linier antara Variabel Independen Exogenus Belanja tidak langsung terhadap Variabel Dependen Endogenus pertumbuhan Ekonomi ialah 0.327.

Pengujian Hipotesis t kriterianya sebagai berikut :

Jika t hitung > t tabel, maka H0 ditolak, dan $\mathrm{H} 1$ diterima

Jika t hitung < t tabel, maka H0 diterima, dan H1 ditolak

Dimana dalam melihat pengaruh signifikan atau tidak Kriterianya adalah sebagai berikut :

Jika Signifikan $<0,05$ maka berpengaruh signifikan

Jika Signifikan > 0,05 maka tidak ada pengaruh signifikan

Hasil dari perhitungan dengan SPSS menunjukan angka $t$ hitung sebesar $0,327<\mathrm{t}$ tabel sebesar 1,894. Dengan demikian keputusanya ialah H0 diterima, dan H1 ditolak. Artinya tidak ada hubungan linier antara Variabel Independen Exogenus Belanja tidak langsung terhadap Variabel Dependen Endogenus pertumbuhan ekonomi. Maka Variabel Independen Exogenus belanja tidak langsung tidak berpengaruh terhadap Variabel Dependen Endogenus Pertumbuhan ekonomi.

Besarnya Koefisien Beta pada tabel 4.6 di atas (dalam kolom Standardized Coefficient Beta) sebesar 0,223 atau jika dibuat persen menjadi sebesar 22,3\% menunjukan bahwa pengaruh sebesar ini belum mampu menjelaskan perubahan yang terjadi pada Belanja Langsung pada tingkat sig 0,752> 0,05. Meskipun sudah mulai menunjukan pertumbuhan dan pengaruh yang positif terhadap terhadap pertumbuhan ekonomi yang terjadi di Kota Bitung, namun alokasi belanja langsung masih belum bisa memberikan kontribusi yang signifikan terhadap pertumbuhan ekonomi. Hal ini dikarenakan alokasi anggaran yang dianggarkan oleh pemerintah daerah sendiri masih amat kecil. sehingga kontribusi pembangunan yang dilakukan oleh pemerintah daerah masih amat kecil efek dan kontribusinya terhadap pertumbuhan ekonomi di Kota Bitung.

\section{Melihat Kelayakan Model Regresi}

Untuk mengetahui model regresi yang telah dibuat sudah benar adalah dengan menggunakan pengujian dengan menggunakan pengujian dengan dua cara, yaitu Pertama 
menggunakan nilai $\mathrm{F}$ pada tabel keluaran ANOVA, dan Kedua dengan cara menggunakan nilai Probabilitas / nilai Sig pada tabel keluaran ANOVA.

Tabel 8 ANOVA(b)

\begin{tabular}{|c|c|c|c|c|c|c|}
\hline \multirow[t]{2}{*}{ Model } & & Sum of Squares & $\mathrm{df}$ & Mean Square & $\mathrm{F}$ & Sig. \\
\hline & Regression & 330709.413 & 2 & 165354.707 & 7.465 & $.015^{\mathrm{b}}$ \\
\hline 1 & Residual & 177194.223 & 8 & 22149.278 & & \\
\hline & Total & 507903.636 & 10 & & & \\
\hline
\end{tabular}

a. Dependent Variable: PE

b. Predictors: (Constant), BL, BTL

Sumber Data : pengolahan data 2017

Uji Hipotesis Menggunakan Angka F. Hipotesis :

H0 : Tidak ada pengaruh linier antara Variabel Independen Exsogenus Belanja langsung

dan Belanja tidak Langsung terhadap Variabel Dependen Endogenus Pertumbuhan

ekonomi.

H1 : Ada pengaruh linier antara Variabel Independen Exogenus belanja langsung dan

belanja tidak langsung terhadap Variabel Dependen Endogenus pertumbuhan ekonomi.

Menghitung nilai $\mathrm{F}$ tabel dengan Ketentuan besar nilai taraf Signifikansi sebesar 0,05 dan Nilai Degree Of Freedom dengan ketentuan Numerator / Vektor 1: Jumlah Variabel -1 atau $3-1=2$, dan dumerator / Vektor 2 : jumlah kasus-jumlah variabel atau $10-3=7$. Dengan ketentuan terdebut diperoleh angka $\mathrm{F}$ tabel sebesar 4,740.

Dengan kriteria pengambilan keputusan hasil pengujian hipotesis

Jika F hitung > F tabel, maka H0 ditolak, H1 diterima.

Jika F hitung < F tabel, maka H0 diterima dan H1 ditolak.

Hasil uji hipotesis adalah :

Hasil perhitungan dengan SPSS didapatkan angka $\mathrm{F}$ hitung sebesar 7,465 > F tabel sebesar 4,740.

Dengan demikian H0 ditolak, dan H1 diterima. Artinya ada hubungan linier antara Variabel Independen Eksogenus belanja langsung dan belanja tidak langsung dengan Variabel Dependen Endogenus pertumbuhan ekonomi. Dengan nilai Sig 0,015 dengan demikian dapat diambil kesimpulan bahwa model regresi di atas sudah layak dan benar.

Perhitungan Struktur II

Pengujian Asumsi klasik

Multikolerasi

Tabel 9 VIF Coefficients ${ }^{a}$

\begin{tabular}{|lll|}
\hline Model & Collinearity Statistics \\
\cline { 2 - 3 } & (Constant) & VIF \\
\hline 1 & BL & 1.669 \\
& BTL & 1.669 \\
\hline
\end{tabular}

Sumber Data : pengolahan data 2017

Dilihat dari tabel 9 Coefficients nilai VIF pada Output menunjukkan keberadaan multikolinearitas.

Bila VIF $<10,00$ maka tidak terjadi gejala Multikolerasi

Bila VIF > 10,00 maka terjadi gejala Multikolerasi

Dengan Hasil :

Nilai VIF $\quad$ : X1 Belanja Langsung $=1,669$

$\mathrm{X} 2$ Belanja tidak langsung $\quad=1,669$ 
Dari hasil perhitungan di atas dapat dilihat bahwa nilai VIF kedua variable independent berada pada angka dibawah 10 hal ini menunjukan bahwa tidak terjadi gejala multikolinearitas sehingga data penelitian layak dan dapat digunakan.

\section{Diagram Uji Heterokoledasitas}

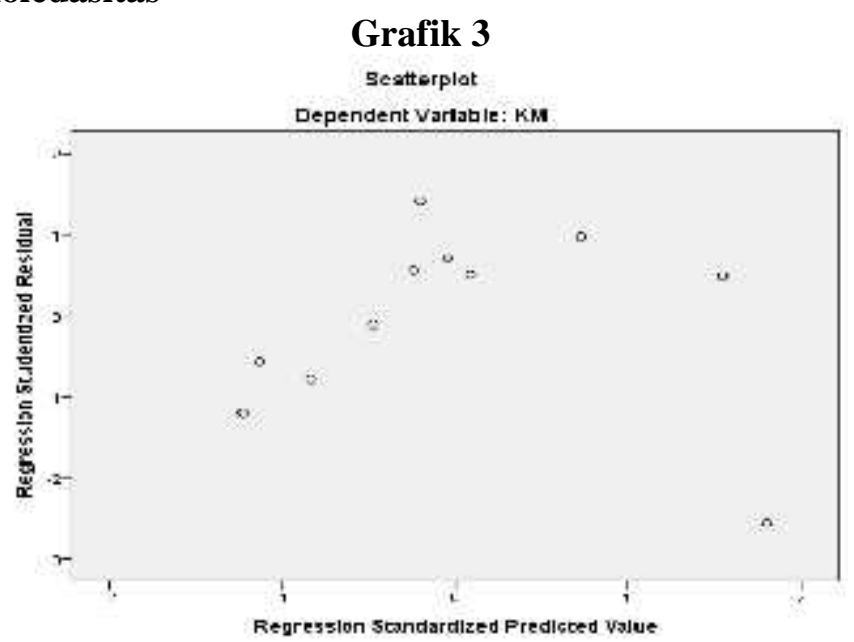

Dari diagram diatas tersebut terlihat bahwa penyebaran residual tidak teratur. Hal tersebut terlihat pada plot yang terpancar dan tidak membentuk pola tertentu. Dengan hasil demikian, kesimpulan yang biasa diambil adalah bahwa tidak terjadi gejala homokedastisitas atau persamaan regresi memenuhi asumsi heterokedatisitas.

\section{Uji Autokorelasi}

Table 10 Model Summary ${ }^{b}$

\begin{tabular}{|l|l|l|l|}
\hline Model & Change Statistics & Durbin-Watson \\
\cline { 2 - 4 } & df2 & Sig. F Change & \\
\hline 1 & $8^{\mathrm{a}}$ & .087 & 1.138 \\
\hline
\end{tabular}

Sumber Data : pengolahan data 2017

Pada analisis regresi telihat bahwa nilai DW 1.821 dan nilai DL 0.455 , dan DU 2,287 . DL < DW < DU yakni 0.455 DL, 1.138 DW, 2.287 DU. berada pada antara DL dan DU dan berada pada titik tengah. Maka dapat disimpulkan bahwa terdapat gejala autokorelasi yang lemah. Hasil Perhitungan (output) untuk substruktur dua dengan menggunakan SPSS 21,0 adalah sebagai berikut : 
Tabel 11 Correlations

\begin{tabular}{|ll|l|l|l|}
\hline \multicolumn{1}{|c|}{} & KM & BL & BTL \\
\hline \multirow{3}{*}{ Pearson Correlation } & KM & 1.000 & -.675 & -.649 \\
& BL & -.675 & 1.000 & .952 \\
& BTL & -.649 & .952 & 1.000 \\
Sig. (1-tailed) & KM &. & .011 & .015 \\
& BL & .011 &. & .000 \\
& BTL & .015 & .000 &. \\
& KM & 11 & 11 & 11 \\
N & BL & 11 & 11 & 11 \\
& BTL & 11 & 11 & 11 \\
\hline
\end{tabular}

Sumber Data : pengolahan data 2017

Dari tabel 11 Correlations diatas menunjukan bahwa Koefisien Korelasi Pearson Belanja langsung dengan alokasi kemiskinan adalah -0,675. dengan nilai sig 0,011, koefisien korelasi antara Belanja tidak langsung dan kemiskinan. Dari hasil tabel Correlations diatas menunjukan -0,649 dengan nilai signifikan 0,015. Dengan demikian dilihat dalam kondisi tersebut dimana nilai signifikan $<0,05$. Maka kesimpulan yang diambil adalah $\mathrm{H} 0$ di tolak, dan $\mathrm{H} 1$ di terima. Yang berarti Koefisien Korelasi adalah signifikan secara statistik.

\section{Penghitungan Koefisien Determinasi}

Tabel 12 Model Summary ${ }^{\mathrm{b}}$

\begin{tabular}{|l|l|l|l|l|l|l|l|}
\hline Model & $\mathrm{R}$ & R Square & $\begin{array}{l}\text { Adjusted R } \\
\text { Square }\end{array}$ & $\begin{array}{l}\text { Std. Error of the } \\
\text { Estimate }\end{array}$ & $\begin{array}{l}\text { Change Statistics } \\
\text { R Square } \\
\text { Change }\end{array}$ & F Change & df1 \\
\hline 1 & $.676^{\mathrm{a}}$ & .456 & .320 & .05868 & .456 & 3.358 & 2 \\
\hline
\end{tabular}

a Predictors: (Constant), BL, BTL

b Dependent Variable: Kemiskinan

Sumber Data : pengolahan data 2017

Dalam melihat pengaruh Variabel Independen Exogenus Belanja Langsung dan Belanja Tidak langsung secara gabungan terhadap variabel Dependen Endogenus Kemiskinan dapat dilihat dari Tabel 12 Model Summary diatas, pada nilai R square. Besarnya $R$ square $\left(R^{2}\right)$ pada tabel dibawah ini adalah 0,456. Angka tersebut mempumpunyai makna Besarnya pengaruh Variabel indeependen exogenous Belanja Langsung dan Belanja Tidak Langsung terhadap variabel dependen endogenus Kemiskinan secara gabungan. Dalam menghitung Koefisien Determinasi (KD) dapat diketahui dengan rumus

$$
\begin{aligned}
& \mathrm{KD}=\mathrm{R} 2 \times 100 \% \\
& \mathrm{KD}=0,456 \times 100 \% \\
& \mathrm{KD}=45,6 \%
\end{aligned}
$$

Besarnya pengaruh Variabel Independen Exogenous Belanja Langsung dan Belanja Tidak langsung terhadap Variabel Dependen Endogenus Kemiskinan secara gabungan adalah 45,6 \%. Dan pengaruh di luar model dapat di hitung dengan rumus :

$$
\begin{aligned}
& \mathrm{e}=1-\mathrm{R}^{2} \\
& \mathrm{e}=1-0,456 \\
& \mathrm{e}=0,544 \times 100 \% \\
& \mathrm{e}=54,4 \%
\end{aligned}
$$


Yang berarti 54,4 \% besarnya faktor lain yang mempengaruhi diluar model yang di teliti. Artinya besarnya pengaruh variabel independen eksogenus Belanja langsung dan Belanja Tidak langsung terhadap variabel dependen endogenus kemiskinan adalah sebesar 45,6 \%, sedangkan pengaruh sebesar 54,4 \% disebabkan oleh variabel di luar model yang di teliti.

\section{Pengaruh variabel independen exogenous Belanja Langsung dan Belanja Tidak langsung secara parsial terhadap variabel dependen endogenus Kemiskinan.}

Besarnya pengaruh variabel independen exogenous Belanja Langsung dan Belanja Tidak langsung terhadap variabel dependen endogenus Kemiskinan secara Parsial dapat dilihat dari nilai Beta atau Standardized Coefficients .dan untuk pengujian digunakan nilai t. Dapat dilihat pada Tabel 13 dibawah ini.

Tabel 13 Coefficients(a)

\begin{tabular}{|c|c|c|c|c|c|c|}
\hline \multirow{2}{*}{\multicolumn{2}{|c|}{$\overline{\text { Model }}$}} & \multicolumn{2}{|c|}{ Unstandardized Coefficients } & \multirow{2}{*}{$\begin{array}{l}\text { Standardized } \\
\text { Coefficients } \\
\text { Beta }\end{array}$} & \multirow[t]{2}{*}{ t } & \multirow[t]{2}{*}{ Sig. } \\
\hline & & $\mathrm{B}$ & Std. Error & & & \\
\hline \multirow{3}{*}{1} & (Constant) & 6.445 & 1.015 & & 6.349 & .000 \\
\hline & BL & -.176 & .247 & -.608 & -.715 & .495 \\
\hline & BTL & -.023 & .283 & -.070 & -.082 & .936 \\
\hline
\end{tabular}

a. Dependent Variable: Kemiskinan

Sumber Data : pengolahan data 2017

\section{Pengaruh Variabel Independen Exogenous Belanja langsung terhadap Variabel Dependen Endogenus Kemiskinan.}

Untuk melihat apakah ada Pengaruh Linier Variabel Independen Exogenus Belanja Langsung terhadap Variabel Dependen Endogenus Kemiskinan. Dapat dilihat pada tabel 4.12 Coefficients(a) Dengan Analisis Hipotesis :

H0 : Tidak ada pengaruh linier antara Variabel Independen Exogenus Belanja langsung terhadap Variabel Dependen Endogenus Kemiskinan.

H1 : Ada Pengaruh linier antara Variabel Independen Exogenus Belanja langsung terhadap

Variabel Dependen Endogenus Kemiskinan

Menentukan besarnya taraf Signifikan sebesar 0,05 dan Degree of Freedom DF $=n-(K+1)$ atau $\mathrm{DF}=10-(2+1)=7$. Dari ketentuan tersebut diperoleh $\mathrm{t}$ tabel sebesar 1,894 (untuk uji dua arah) Dalam perhitungan SPSS yang tertera pada tabel Coefficients di atas dimana $t$ hitung adalah untuk menunjukan bahwa adanya Pengaruh linier antara Variabel Independen Exogenus Belanja langsung terhadap Variabel Dependen Endogenus Kemiskinan ialah -0,715.

Pengujian Hipotesis t kriterianya sebagai berikut :

Jika thitung $>\mathrm{t}$ tabel, maka $\mathrm{H} 0$ ditolak, dan $\mathrm{H} 1$ diterima

Jika t hitung < $\mathrm{t}$ tabel, maka $\mathrm{H} 0$ diterima, dan $\mathrm{H} 1$ ditolak

Dimana dalam melihat pengaruh signifikan atau tidak Kriterianya adalah sebagai berikut :

Jika Signifikan $<0,05$ maka berpengaruh signifikan

Jika Signifikan >0,05 maka tidak ada pengaruh signifikan

Hasil dari perhitungan dengan SPSS menunjukan angka t hitung sebesar $-0,715<\mathrm{t}$ tabel sebesar 1,894. Dengan demikian keputusanya ialah H0 diterima, dan H1 ditolak. Artinya tidak ada hubungan linier antara Variabel Independen Exogenus Belanja Langsung terhadap Variabel Dependen Endogenus Kemiskinan. Maka Variabel Independen Exogenus Belanja langsung tidak berpengaruh terhadap Variabel Dependen Endogenus Kemiskinan. Besarnya Koefisien Beta pada tabel 4.6 di atas (dalam kolom Standardized Coefficient Beta) sebesar -0,608 atau jika dibuat persen 
menjadi sebesar 60,8 \% menunjukan bahwa pengaruh sebesar ini tidak mampu menjelaskan perubahan yang terjadi pada Belanja Langsung, terlebih karena karena nilai signifikansi / probabilitas hasil yang tertera pada kolom Sig 0,495 > 0,05. Kemampuan Belanja langsung yang dilakukan oleh pemerintah berdasarkan penelitian ini menunjukan bahwa efek atau pengaruhnya masih amat kecil diakibatkan oleh kurangnnya anggaran belanja langsung yang dilakukan, selain itu pertumbuhan alokasi belanja langsung di Kota Bitung juga tidak sebesar pertumbuhan kemiskinan yang terjadi sehingga terkesan memberikan pengaruh yang tidak signifikan.

\section{Pengaruh antara variabel Independen Exogenus Belanja Tidak langsung terhadap Variabel Dependen Endogenus Kemiskinan.}

Untuk melihat apakah ada Pengaruh Linier Variabel Independen Exogenus Belanja Tidak langsung terhadap Variabel Dependen Endogenus belanja langsung. Dapat dilihat pada tabel 13 Coefficients(a) Dengan Analisis Hipotesis :

H0 : Tidak ada pengaruh linier antara Variabel Independen Exogenus Belanja tidak langsung terhadap Variabel Dependen Endogenus Belanja kemiskinan.

H1 : Ada Pengaruh linier antara Variabel Independen Exogenus belanja tidak langsung terhadap Variabel Dependen Endogenus kemiskinan

Menentukan besarnya taraf Signifikan sebesar 0,05 dan Degree of Freedom DF $=n-(K+1)$ atau $\mathrm{DF}=10-(2+1)=7$. Dari ketentuan tersebut diperoleh t tabel sebesar 1,894 (untuk uji dua arah) Dalam perhitungan SPSS yang tertera pada tabel Coefficients di atas dimana t hitung adalah untuk menunjukan bahwa adanya Pengaruh linier antara Variabel Independen Exogenus belanja tidak langsung terhadap Variabel Dependen Endogenus kemiskinan ialah -0,082. Pengujian Hipotesis t kriterianya sebagai berikut :

Jika thitung $>\mathrm{t}$ tabel, maka $\mathrm{H} 0$ ditolak, dan $\mathrm{H} 1$ diterima

Jika t hitung < t tabel, maka H0 diterima, dan H1 ditolak

Dimana dalam melihat pengaruh signifikan atau tidak Kriterianya adalah sebagai berikut : Jika Signifikan $<0,05$ maka berpengaruh signifikan

Jika Signifikan > 0,05 maka tidak ada pengaruh signifikan

Hasil dari perhitungan dengan SPSS menunjukan angka $t$ hitung sebesar $-0,082<\mathrm{t}$ tabel sebesar 1,894. Dengan demikian keputusanya ialah H0 diterima, dan H1 ditolak. Artinya tidak ada hubungan linier antara Variabel Independen Exogenus Belanja tidak langsung terhadap Variabel Dependen Endogenus Kemiskinan. Maka Variabel Independen Exogenus Belanja tidak langsung tidak berpengaruh terhadap Variabel Dependen Endogenus kemiskinan. Besarnya Koefisien Beta pada tabel 4.12 di atas (dalam kolom Standardized Coefficient Beta) sebesar 0,070 atau jika dibuat persen menjadi sebesar $7 \%$ menunjukan bahwa pengaruh sebesar ini tidak mampu menjelaskan perubahan yang terjadi pada Belanja Langsung pada tingkat koefisien sebesar 0,05 . Pengaruh yang diberikan oleh alokasi belanja tidak langsung terhadap pemberantasan kemiskinan di kota Bitung memang saat ini masih amat kecil dikarenakan kurangnnya alokasi anggaran dan pertumbuhan kemiskinan di kota Bitung yang bisa dikatakan bertumbuh dengan cepat namun bisa disiasati pemerintah kota Bitung dengan mengundang investasi dari pihak luar.

\section{Melihat Kelayakan Model Regresi}

Untuk mengetahui model regresi yang telah dibuat sudah benar adalah dengan menggunakan pengujian dengan menggunakan pengujian dengan dua cara, yaitu Pertama menggunakan nilai $\mathrm{F}$ pada tabel keluaran ANOVA, dan Kedua dengan cara menggunakan nilai Probabilitas / nilai Sig pada tabel keluaran ANOVA. 
Tabel 14 ANOVA(b)

\begin{tabular}{|ll|l|l|l|l|l|}
\hline Model & & Sum of Squares & df & Mean Square & F & Sig. \\
\hline \hline & Regression & .023 & 2 & .012 & 31.358 & $.087^{\mathrm{b}}$ \\
\hline & $\begin{array}{l}\text { Residual } \\
\text { Total }\end{array}$ & .028 & 8 & .003 & & \\
\hline
\end{tabular}

a. Dependent Variable: KM

b. Predictors: (Constant), BL, BTL

Sumber Data : pengolahan data 2017

Uji Hipotesis Menggunakan Angka F. Hipotesis :

H0 : Tidak ada pengaruh linier antara Variabel Independen Exsogenus Belanja

langsung dan Belanja Tidak langsung terhadap Variabel Dependen Endogenus

Kemiskinan.

H1 : Ada pengaruh linier antara Variabel Independen Exogenus Belanja langsung

dan Belanja Tidak Langsung terhadap Variabel Dependen Endogenus Kemiskinan.

Menghitung nilai $F$ tabel dengan Ketentuan besar nilai taraf Signifikansi sebesar 0,05 dan Nilai Degree Of Freedom dengan ketentuan Numerator / Vektor 1: Jumlah Variabel -1 atau $3-1=2$, dan dumerator / Vektor 2 : jumlah kasus-jumlah variabel atau $10-3=7$. Dengan ketentuan terdebut diperoleh angka $\mathrm{F}$ tabel sebesar 4,740. Dengan kriteria pengambilan keputusan hasil pengujian hipotesis

Jika F hitung > F tabel, maka H0 ditolak, H1 diterima.

Jika F hitung < F tabel, maka H0 diterima dan H1 ditolak.

Hasil uji hipotesis adalah :

Hasil perhitungan dengan SPSS didapatkan angka F hitung sebesar 31,385 > F tabel sebesar 4,740.

Dengan demikian H0 ditolak, dan H1 diterima. Artinya ada hubungan linier antara Variabel Independen Eksogenus Belanja Langsung dan belanja tidak langsung dengan Variabel Dependen Endogenus Kemiskinan. Dengan nilai Sig 0,008 dengan demikian dapat diambil kesimpulan bahwa model regresi di atas sudah layak dan benar.

\section{Pembahasan}

Berdasarkan hasil penelitian yang dilakukakan didapatkan hasil bahwa alokasi belanja pemerintah baik melalui alokasi belanja langsung maupun alokasi belanja tidak langsung belum bisa memacu pertumbuhan ekonomi dengan signifikan, hal ini dikarenakan, meski pengalokasian dana belanja dari pemerintah baik belanja langsung maupun tidak langsung yang terus naik dan tumbuh setiap tahunnya tidak berjalan beriringan dengan pertumbuhan ekonomi yang terjadi bahkan, pertumbuhan ekonomi seakan tidak terpengaruh dengan perubahan alokasi anggaran dari belanja yang dilakukan oleh pemerintah, hal ini bisa disebabkan salah satunya adalah pengalokasian anggaran belanja yang tidak terfokus pada sektor-sektor perekonomian yang dapat memacu pertumbuhan ekonomi di daerah. Yang yang hampir sama juga terjadi pada angka kemiskinan yang ada, alokasi belanja dari pemerintah tidak dapat mempengaruhi dengan signifikan perubahan angka kemiskinan yang terjadi, hal ini tentu tidak sejalan dengan visi pemerintah untuk dapat mereduksi kemiskinan melalui anggaran publik. Seperti hasil penelitian yang dilakukan tidak didapatkan faktor berarti dari alokasi belanja pemerintah baik langsung maupun tidak langsung terhadap pertumbuhan ekonomi maupun angka kemiskinan.

\section{DAFTAR PUSTAKA}

Abdul Halim (2009). Sistem Pengendalian Manajemen. UPP STIM YKPN. Cetakan Ketiga Maret. Abdul Halim. (2003). Analisis Investasi. Edisi Pertama, Penerbit Salemba Empat : Jakarta 
Ala, Andre Bayo, 1996, Kemiskinan dan strategi memerangi kemiskinan. Yogyakarta : Penerbit Libety.

Anis Setiyawati, Ardi Hamsah, 2007, Analisis Pengaruh PAD, DAU, DAK dan Belanja pembangunan terhadap pertumbuhan ekonomi, kemiskinan dan pengaguran

Ardi Hamzah, 2006, Analisis Kinerja Keuangan Terhadap Pertumbuhan Ekonomi Pengangguran dan Kemiskinan,(studi pada 29 kota kabupaten dan 9 kota di Propinsi Jawa Timur periode 2001-2006)

Bastian, Indra, Gatot Soepriyanto, 2002. Sistem Akuntansi Sektor Publik Konsep Untuk Pemerintah Daerah, Edisi Pertama, Salemba Empat, Jakarta.

Chen, S. and M. Ravallion. (2001). Measuring Pro-Poor Growth: Martin Ravallion and Shaohua Chen. Vol. 2666. Washington: The World Bank, Development Research Group, Poverty.

Gafar,T Ijaiya, Mukaila A, Ijaiya, Raji A. Bello, Michael A. Ajayi, 2011, Economic Growth and poverty reduction in Nigeria

Gujarati, Damodar. 2003. Ekonometrika Dasar : Edisi Keenam. Jakarta: Erlangga.

Ghozali, Imam. 2006. “Aplikasi Analisis Multivariate Dengan Program SPSS”.Semarang : Badan Penerbit Undip

Heidegger,Martin,2011 Being and Time, San Fransisco: Harper Collins Publishers.

Jonathan Sarwono, 2006, Metode Penelitian Kuantitatif \& Kualitatif, (Yogyakarta; Graha Ilmu,

Kappel, R., J. Lay and S. Steiner. (2005). Uganda: No More Pro-poor Growth? Development Policy Review 23(1): 27-53. Robert D. Retherford 1993

Kuncoro, Mudrajat, 2004, Otonomi dan Pembangunan Daerah, Erlangga, Jakarta

Matleena Kniivilä, 2010, Industrial development and economic growth: Implications for poverty reduction and income inequality

Mardiasmo. 2002. Akuntansi Sektor Publik. Penerbit Andi. Yogyakarta.

Musa Asy'arie, 2011 pak guru kami sebuah persembahan untuk 60 tahun Musa Asy'arie, LESFI, Yogyakarta.

Santoso, singgih dan tjiptono, fandy, 2001, riset pemasaran: konsep dan aplikasi dengan spss, pt elex media komputindo, jakarta.

Sekaran, uma. 1992. "research methods for business". Third edition. Southern illionis university.

Santoso singgih, 2002. Mengolah data statistik secara prefesional, jakarta: penerbit pt elex media komputindo, hlm 143-231.

Sadono Sukirno, 2006, Ekonomi Pembangunan Proses masalah dan Dasar Kebijakan, cetakan ketiga, Penerbit Kencana, Jakarta.Aisyah, 2000

Todaro, MP.2000. Economic Development seventh edition, Longman Inc.England.

The World Bank. (2014). INDO-DAPOER (Indonesia Database for Policy and EconomicResearch).http://databank.worldbank.org/data/views/variableselection/selectvaria bles.aspx? source=indo dapoer-\%28indonesia-database-for-policy-and-economicresearch\%29, diakses pada tanggal 5 Agustus 2014.

-------------Undang-Undang No.32 Tahun 2004 Tentang Pemerintahan Daerah (Lembaran Negara Republik Indonesia Tahun 2004 Nomor 125)

--------------Undang-Undang No.33 tahun 2004 Tentang Perimbangan Keuangan Antara Pemerintah Pusat Dan Pemerintah Daerah. ( Lembaran Negara Republik Indonesia Tahun 2004 Nomor 126)

Peraturan Pemerintah No. 58 Tahun 2005 Tentang Pengelolaan Keuangan Daerah BPS Propinsi Sulawesi Utara 